\title{
The Effect of Cost Recovery Mechanism in Production Sharing Contract (PSC) in Oil and Gas Industry in Indonesia
}

\author{
Patricia Audrey R \\ Faculty of Law \\ Brawijaya University \\ Malang, Indonesia \\ patricia@ub.ac.id
}

\author{
Ikaningty as \\ Faculty of Law \\ Brawijaya University \\ Malang, Indonesia \\ ninktyas@ub.ac.id
}

\author{
Rika Kurniaty \\ Faculty of Law \\ Brawijaya University \\ Malang, Indonesia \\ rika_kurniaty@ub.ac.id
}

\begin{abstract}
This paper aims to explain the normative rules relating to cost recovery as a basis for profit sharing between the government and the contractors in oil and gas agreements, and the implementation of those agreements. As the exploration and exploitation of oil and gas is a strategic industry for Indonesia, wherein oil and gas industry contributes $30 \%$ of the Indonesian state budget. In the management of national oil and gas industry, foreign investors are often involved with Production Sharing Contract. This Production Sharing Contract between the government and investors usually done after cost recovery reduction was made. With a normative juridical and conceptual approach, show there is existence of inconsistency in the implementation of cost recovery in Production Sharing Contract (PSC) of oil and gas procurement, particularly regarding the components that should exist in cost recovery contract of oil and gas cooperation in Indonesia.

The amount of cost recovery value will greatly affect the amount for the production of oil and gas. Although it has been regulated in government regulation number 79 Year 2010 on operating cost of re-refundable and tax revenue in the field of oil and gas business, which states that there are 3 components of cost recovery: capital cost, non-capital cost, and depreciation, however there are still many disobediences to the implementation of cost recovery in the field
\end{abstract}

Keywords-cost recovery, production sharing contract (psc), oil and gas, indonesia

\section{INTRODUCTION}

Oil and gas exploration and exploitation activities in Indonesia are very strategic industries, especially Indonesia is a country that has the largest oil reserves in the Southeast Asia region. The strategic position of oil and gas industry is also related to the process of legal regulation regarding mining activities in the history of Indonesia. It began in 1899, with Indische Mijn Wet (IMW) under the Dutch East Indies government claiming their control over minerals and metals in Indonesia[1]. At that time, the used oil and gas management system was a concession system, which was a system that gave mining contractors the freedom to have full rights over the control of land and natural resources, as well as the mining business operators and mining authority holders [2]. The contractor's obligation to the Dutch government is only to pay taxes and royalties. In 1910, IMW was equipped with Mijordonnaantie (Mining Ordinance)[3].
In 1945 when Indonesia took its independence, it is where the Government nationalized Oil and Gas assets which previously controlled by foreign parties. It also changed the Oil and Gas business system, that was the concession system into Contract of Work system. This is adjusted to the values of control to Indonesia's natural wealth as stipulated in article 33 of the 1945 Constitution and strengthened by the birth of Law No. 44 Year 1960 concerning Oil and Gas Mining[2]. ${ }^{1}$

Later, during the New Order era, precisely with the is suance of the Law on State Oil and Gas Mining Company No. 8 Year 1971, the government also introduced a system of revenue sharing agreements between investors and the Government. The point is that Production Sharing Contract is a profit sharing system in form of crude oil production sharing system between the government with the Cooperation Contract Contractor (CCC). Production Sharing Contract (PSC) experienced 3 times of changes, where in the third change, the profit sharing percentage is as follows:

a. Petroleum: $85 \%$ for the implementing agencies and $15 \%$ for business entities and / or permanent business entities

b. Natural gas: $70 \%$ for the implementing agencies and $30 \%$ for business entities and / or permanent business entities[2].

Profit sharing system between the Government and CCC is carried out after being reduced by cost recovery[4]. ${ }^{2}$ Therefore, after oil production begins to run, some of the results become a share for the contractor as payments for the costs incurred during the exploration process. The amount of cost recovery paid to the government will directly affect the number of state's revenue from oil and gas sector[5]. Cost Recovery is an important part in oil and gas contract, because the State as the land owner and the organizer of mining activities, can give mining authority to $\mathrm{CCC}$. Cost recovery

the main idea underlying the birth of Law No. 44 of 1960 is: State power to commercialize oil and gas is carried out by the government, with the intention in carrying out the principle of the utilization of natural wealth for the greatest prosperity for the people.

cost recovery is the refund of oil and gas exploration and exploitation costs from the Government to CCC. Cost Recovery is paid in the form of oil and gas production, which is assessed by Weighted Average Price (WAP), that is the weighted average price which calculated based on the lifting value for one year, divided by the number of lift ing units during the same period. 
also prevents the force from oil and gas companies to acquire oil and gas production areas, because the bailout costs for oil and gas production have been replaced through cost recovery.

Oil and gas industry has a different character compared to other industry sectors, because oil and gas industry has high cost, use high technology, possessn high risk industry characteristics, and requires continuous exploration and exploitation. Therefore, with good fiscal arrangements and attractive investment offerings, more and more investors will be willing to cooperate in oil and gas industry in Indonesia.

Unfortunately, supervision on the implementation of cost recovery payments is still very weak. The related case was the 2013 Semester Examination Results Summary which gave alarming results. Financial Monitoring Bureau (FMP/BPK) found that there were 8 non-compliance contractors (CCC) who are violating the provisions of cost recovery and taxation which resulted in a shortage to sate's revenue as much as Rp. 994.8 billion[6]. These events then became problems, such as how is CCC's mechanism in regulating cost recovery in accordance to the rules stipulated in the laws and regulations.

\section{RESULT AND DISCUSSION}

Initially, Production Sharing Contract (PSC) was referred to as a Profit Sharing Contract based on Government Regulation Number 35 Year 1994 concerning the Terms and Guidelines for Cooperation in Oil and Gas Profit Sharing Contracts (PP 35/1994). This idea was introduced by Ibnu Sutowo[7], ${ }^{3}$ who introduced the principles of PSC as follows: (1) company's control is held by the state's company, (2) the contract is based on the distribution of production, (3) all risks are borne by the contractor. If oil is found, then the contractor has the right to reimburse the maximu m cost of $40 \%$ of the total production, but if it fails, then the loss is borne by the contractor. (4) The split between, state's company and contractor is 65:35, (5) as sets purchased by contractor become state's property, with a cost recovery system, (6) state's company pays contractor's income tax to the government, (7) a contractor is obliged to pursue human resource in Indonesia and train and educate them, and (8) contractors must provide $25 \%$ for domestic needs [2]. Thus, the contractor only gets economy rights in Oil and Gas business, while the State holds the ownership rights of oil and gas (mineral rights), and the management rights are held by States company (mining rights)[8].

Ibnu Sutowo is an Indonesian figure (former military) who developed Permina, State oil company, which later turned into Pertamina, and also was once became the Minister of Energy and Mineral Resources. https://id.wikipedia.org/wiki/Ibnu Sutowo, accessed on August 1, 2018. He introduced the management of Indonesian oil and gas with a system of cooperation contracts. This was inspired by Javanese peasants. Some Javanese land farmers are not owners of rice fields, but only cultivators of rice fields that are leased by landowners where they will get wages through a sharing system between the owners of the rice fields and cultivators of the rice fields. This system is called Maron system. This system was then applied to the oil and gas industry in Indonesia which emphasized the existence of a profit sharing system between the Government, as the owner of land and natural resources, with the contractor, as the holder of oil and gas mining authority.
TABLE 1

DIFFERENCE OF CONTRACTS ON OIL AND GAS MANAGEMENT IN INDONESIA

\begin{tabular}{|c|c|c|c|c|}
\hline Distinctions & Consession & $\begin{array}{c}\text { Contract of } \\
\text { Work }\end{array}$ & PSC & PSC \\
\hline Legal basis & $\begin{array}{l}\text { Indische } \\
\text { Mijnwet } \\
\text { No } \\
214 / 1899\end{array}$ & $\begin{array}{c}\text { Law } \\
\text { number } 44 \\
\text { Yera } 1960 \\
\text { on the } \\
\text { Mining of } \\
\text { Oil and } \\
\text { Natural Gas }\end{array}$ & $\begin{array}{c}\text { Law } \\
\text { Number } 8 \\
\text { Year 1971 } \\
\text { on State's } \\
\text { Oil Mining } \\
\text { Company } \\
\text { (Pertamina) }\end{array}$ & $\begin{array}{c}\text { Law } \\
\text { Number } 22 \\
\text { Year } 2001 \\
\text { on Oil and } \\
\text { Natural } \\
\text { Gas }\end{array}$ \\
\hline $\begin{array}{c}\text { Manageme } \\
\text { nt }\end{array}$ & Contractor & Contractor & $\begin{array}{l}\text { Pertamina/ } \\
\text { Government }\end{array}$ & $\begin{array}{c}\text { Pertamina/ } \\
\text { Implementi } \\
\text { ng Agency } \\
\text { on Oil and } \\
\text { Gas (BP } \\
\text { Migas) }\end{array}$ \\
\hline $\begin{array}{c}\text { Oil and } \\
\text { Gas } \\
\text { Ownership }\end{array}$ & Contractor & Government & Government & Government \\
\hline $\begin{array}{c}\text { Assets } \\
\text { ownership }\end{array}$ & Contractor & Government & Government & Government \\
\hline $\begin{array}{c}\text { State } \\
\text { Revenue }\end{array}$ & $\begin{array}{l}\text { Royalties } \\
\text { and tax }\end{array}$ & $\begin{array}{c}\text { Profit } \\
\text { Sharing }\end{array}$ & $\begin{array}{c}\text { Production } \\
\text { Sharing } \\
\end{array}$ & $\begin{array}{c}\text { Production } \\
\text { Sharing } \\
\end{array}$ \\
\hline
\end{tabular}

\section{A. Implementation and Mechanism of Cost Recovery in Production Sharing Contract (PSC)}

Until 2009, PSC has experienced 3 changes, those are as follow:

TABLE 2

DIFFERENCES OF PSC GENERATION I, II, AND III

\begin{tabular}{|c|c|c|c|c|}
\hline No & $\begin{array}{c}\text { Fiscal } \\
\text { Regulation }\end{array}$ & PSC I & PSC II & PSC III \\
\hline 1 & $\begin{array}{l}\text { First Tranche } \\
\text { Petroleum } \\
\text { (FTP)4 }\end{array}$ & - & - & $20 \%$ \\
\hline 2 & $\begin{array}{c}\text { Cost } \\
\text { Recovery } \\
\text { Limit }\end{array}$ & $40 \%$ & $100 \%$ & $\begin{array}{c}100 \% \text { after } \\
\text { FTP }\end{array}$ \\
\hline \multirow[t]{2}{*}{3} & $\begin{array}{c}\text { Production } \\
\text { Sharing }\end{array}$ & \multirow[t]{2}{*}{$\begin{array}{c}\text { Oil } \\
65 \%: 35 \%\end{array}$} & $\begin{array}{c}\text { Oil } \\
85 \%: 15 \%\end{array}$ & $\begin{array}{c}\text { Oil } \\
85 \%: 15 \%\end{array}$ \\
\hline & $\begin{array}{l}\text { Government } \\
\text { (pertamina): } \\
\text { Contractor }\end{array}$ & & $\begin{array}{c}\text { Natural Gas } \\
70 \%: 30 \% \text { or } \\
65 \%: 35 \% \\
\end{array}$ & $\begin{array}{c}\text { Natural Gas } \\
70 \%: 30 \% \text { or } \\
65 \%: 35 \%\end{array}$ \\
\hline 4 & Tax & $\begin{array}{c}\text { Included in the } \\
65 \% \text { share for } \\
\text { the } \\
\text { government }\end{array}$ & $\begin{array}{c}56 \% \\
48 \% \text { since } \\
1984\end{array}$ & $\begin{array}{c}48 \% \\
44 \% \text { since } \\
1994\end{array}$ \\
\hline 5 & $\begin{array}{l}\text { Domestic } \\
\text { Market } \\
\text { Obligation } \\
(\mathrm{DMO}) 5\end{array}$ & $\begin{array}{c}25 \% \text { of } \\
\text { contractor's } \\
\text { share with the } \\
\text { price USD } 0,2 \\
\text { per barrel }\end{array}$ & $\begin{array}{c}25 \% \text { of } \\
\text { contractor's } \\
\text { share; export } \\
\text { price in the } \\
\text { first } 5 \text { years, } \\
\text { and USD } 0,2 \\
\text { per barrel } \\
\text { afterwards }\end{array}$ & $\begin{array}{c}25 \% \text { of } \\
\text { contractor's } \\
\text { share, export } \\
\text { price in the } \\
\text { first } 5 \text { years, } \\
\text { and USD } 0,2 \\
\text { per barrel } \\
\text { afterwards }\end{array}$ \\
\hline 6 & $\begin{array}{l}\text { Investment } \\
\text { Credit }\end{array}$ & - & $20 \%$ & $18-20 \%$ \\
\hline
\end{tabular}

In November 2012, after 12 years of the promulgation of the Law Number 21 Year 2002 concerning Oil and Gas, a number of community leaders filed a judicial review on a

FTP is CCC's obligation as collateral to fulfill domestic demand on oil and gas.

5 DMO is contractor's obligation to sell some of oil and gas production result for domestic supply. 
number of articles in the Oil and Gas Law, specifically regulating the duties and functions of BP Migas, and the Constitutional Court granted through decision No. 36 / PUU $\mathrm{X} /$ 2012. This decision resulted in the dissolution of BP Migas as the regulator and operator of oil and gas industry in Indonesia[9]. Then came the Presidential Regulation No. 95 Year 2012 dated November 13, 2012 concerning the Transfer of Implementation of Duties and Functions of Upstream Oil and Gas Business Activities, to ensure the sustainability of National Oil and Gas production activities. The Minister of Energy and Mineral Resources also issued a Decree of the Min ister of Energy and Mineral Resources No. $3135 \mathrm{~K}$ / MEM / 2012 which stipulated that the implementation of the duties and functions and organization of BP Migas was transferred to the Provisional Working Unit for Upstream Oil and Gas Business Activities (SKSP Migas) which was directly responsible to the Minister of Energy and Mineral Resources. ${ }^{6}$ After that, the Regulation of the Minister of Energy and Mineral Resource No. 9 Year 2013, the Provisional Work Unit for Upstream Oil and Gas Business Activities (SKSP Migas) was renamed into Special Business Unit for Implementing Upstream Oil and Gas Activities (SKK Migas)

\section{B. Limiting Cost Recovery in PSC in Indonesia}

The regulation regarding cost recovery as described in the previous table has experienced three changes since the enactment of PSC 1960. Starting from limiting cost recovery to a maximum of $40 \%$ of production, then was changed through the new terms of PSC II into no limit on the amount of cost recovery, means that there will be a $100 \%$ refund during the oil and gas production process. This policy then caused losses to the State when faced with the unmaximized oil and gas production, moreover with the increase of world's oil prices below US \$10/ barrel which further decreased the oil and gas sector condition at that time to be getting lower. To overcome this, the government finally is sued new regulations through PSC Generation III.

The limitation of cost recovery by the Government is realized by First Tranche Petroleum (FTP) of $20 \%$ of the total oil and gas production as collateral for the Government to obtain oil and gas production before the profit sharing is carried out. Limitation of cost recovery can provide two implications for domestic oil and gas industry, those are: (1) limiting cost recovery appropriately will result in to more effective and efficient in terms of state revenues. (2) limiting cost recovery can be a barrier to the development of investment in oil and gas sector, therefor it tends to be stagnant[10]. There are four considerations that form the basis for limiting cost recovery, they are[11]:

a. Limiting cost recovery to avoid unnecessary investment

b. Limiting cost recovery will force the contractor to comply with good engineering practice[12]. ${ }^{7}$ To

6 Issuance Letter Number 01/SKSPPW0000/2102/SO, issued by Provisional Working Unit for Upstream Oil and Gas Business Activities (SKSP Migas) in Jakarta in 2012.

basic requisite principles for good en gineering applications :

1. It is necessary to have work performed by employing theoretical and applied methods so as to assimilate information on mathematical and natural sciences.

2 . It is necessary to employ rationally the information gathered. investment decisions that do not comply with these rules, the risk is borne by the contractor alone and should not be imposed on cost recovery.

c. This limitation is also intended to uphold the authority of BP Migas which so far has only been deemed not to act decisively to impose sanctions on violations committed by contractors, for example the realization of cost recovery that exceeds the initial calculation.

d. Limiting on cost recovery will make the contractors think twice about including costs that planned in production costs, so they will carelessly distribute fundings.

Regulations concerning limiting cost recovery greatly have implications for state's revenues. The greater the cost recovery that must be paid, the greater the reduction in state's revenues. For example, in the 2010 State Budget, the maximu $\mathrm{m}$ cost recovery that is tolerated is US \$ $13.1 \mathrm{M}$. The amount increases when compared to 2009 (US \$11.05M). The realization is that the swelling of the amount exceeded the maximum of State Budget which will then be a burden to the State on the cost recovery in the next period. This condition will result in a budget deficit in the current State Budget which means that the Government is in arrears in debt which should be paid[13]. As an effort to protect revenues and avoid state losses and provide a clear legal basis, the Minister of Energy and Mineral Resources then is sued Ministerial Regulation No. 22 Year 2008 concerning types of upstream oil and gas business activities that cannot be returned to the cooperation contractor. This Ministerial Regulation contains 17 points of negative list of cost recovery. The implementation of costs that can be included in cost recovery is rearranged in Government Regulation No. 79 Year 2010 concerning returnable operating costs and treatment of income tax in Oil and Gas upstreambusiness.

\section{Component of Costs in Cost Recovery}

Government Regulation (GR) No. 79 Year 2010 regulates the types of costs that can be included in the cost recovery list, as follows:

a. current year Non-Capital Cost

Refers to operating costs incurred in connection with current year operations. In addition to costs related to current operations, it also includes [14]:

(i) Operational, labor, materials and services used in the operation of oil wells, production of oil field operating facilities, up to repairing, maintenance, and marketing activities.

(ii) Office, services, general administration

(iii) Drilling Production, proven well drilling, redrilling, recompleting wells and road access leading directly to the well

(iv) Exploration drilling, labor, services used in drilling wells by finding proven objects of oil and gas

(v) Survey

3. The objective is to develop methods by using such information for the utilization of materials and forces in ways other than found in their original state in nature.

4. It is essential that findings attained by the use of such methods convey benefit to mankind.

5. It is required to have the developed methods economically viable 
(vi) Other exploration expenditures, additional facilities used in exploration and purchased and geophysical geological information within one year or less of the current year.

b. Current Year's depreciation for capital cost

Refers to expenditure for costs that generally have benefits.

(i) construction, utilities, auxilliaries, namely workshops, water and electricity facilities, warehouses, cargo ports, and road fields, except those which has been mentioned in points 3 and 4

(ii) housing and welfare development for oil and gas industry employees

(iii) production facilities

(iv) movables, surface and subsurface of drilling and the drilling, and production of tools, equipment and instruments, barges, automotive equipment, aircraft, construction equipment, furniture and office equipment and others.

c. Depreciation

Depreciation will be calculated starting from the calendar year in which assets are placed into a service with full year depreciation allowed for the beginning of the calendar year. The method used to calculate depreciation every year that allowed for initial capital costs is the declining balance method. Calculation of each year is allowed to recover the cost of capital which must be based on the cost of capital of individual assets at the beginning of the year as multiplied by the depreciation factor as follows, other costs that can be included in operating costs include:

(i) overhead allocation, is the administrative fee incurred by the company other than cost direct changes related to its operations in Indonesia[15].

(ii) Non-capital inventory, is a cost that arises after the procurement of goods carried out by a company or contractor landed in port impirt, these costs include operating costs.

(iii) Interest Recovery, is the interest expense from loans originating from affiliates, parent companies, and third parties

(iv) Insurance

(v) Costs for moving gas from the collection point to the delivery point

(vi) Costs after upstream oil and gas activities.

\section{Components of Cost that cannot be Categorized as Cost Recovery}

The following are 24 points of negative list of Cost Recovery in GR No. 79 Year 2010 article 13, those are:

a. Fees charged or issued for personal and / or family interests of workers, leaders, participating interest holders and shareholders

b. Establishment or fertilization of reserve funds

c. Donated property

d. Administrative sanctions due to contractor's mistake, either deliberately or by negligence

e. Depreciation fees for used goods and equipment that do not belong to the state f. Incentives, payment of pension contributions, insurance premiums for personal and / or family interests for foreign workers, management, and shareholders

g. The cost of foreign workers who do not fulfill the procedure or do not hold a foreign worker license

h. Legal consultant fees that are not directly related to petroleum operations in the frame work of a cooperation contract

i. Tax consultant fees

j. Marketing costs for oil and / or natural gas that become the contractor's share, unless approved by the head of the implementing agency

k. Pepresentation fees

1. Costs for the development of the environment and local communities during exploitation

$\mathrm{m}$. The cost of technical training for foreign workers

n. Costs related to mergers, acquisitions, or transfer fees

o. Costs on interest of loans

p. Employee income tax

q. Procurement of goods and services and other activities that are not in accordance with the principles of fairness [16] ${ }^{8}$ and good engineering practices, or that exceed the approval value of authorization for expenditure above $10 \%$ of the value of the expenditure authorization.

r. Excessive material surplus due to planning and purchase errors

s. The book value and operating costs of assets that have been used and cannot be operated again due to the negligence of the contractor

t. Transactions that: harm the state, not through tender procedures in accordance with the provisions of the prevailing laws and regulations, and against the laws and regulations

u. Bonuses paid to the government

v. Costs incurred prior signing the contract

w. Interest recovery incentives

x. Commercial audit fees

GR No. 79 Year 2010 applies to all active PSCs, including PSCs that have been signed before the issuance of this GR

\section{E. Implication of Cost Recovery Towards State Revenue}

Oil and gas sector contributes $28-30 \%$ of the total state revenue in the State Budget[17]. This revenue is in the form of Contractor Income Tax (PPh) and Non-Tax State Revenue (PNBP). Based on the 2013 SKK Migas Annual Report, the amount of state revenues for the period of January to December 2013 reached US \$ 31.08 billion, with details for oil revenues was US \$ 18.6 billion, and gas was US \$ 12.42 billion[18]. Oil and gas sector has become a major driver in national development and reached its heyday in the New

Principle of Fair and Prevalent Business Conduct (arm's length principle) is a principle that regulates that in the case of conditions in transactions carried out between parties who have Special Relationships as equal or comparable with conditions in transactions conducted bet ween parties who do not have Special Relationships that are used as a comparison, the price or profit in a transaction made between the parties that have the said Special Relationship must be the same as or be in the range of prices or the range of profits in the transaction made between the parties that do not have a Special Relationship which is used as a comparison. 
Order era, where oil and gas sector contributed $60 \%$ to state revenue[19]. However, in 1996 oil and gas production began to show a decline, and the peak was in 2005, where it declined from 1.4 million barrels / day to 930 thousand barrels / day. In addition to the natural decline, there are also technical issues, namely dried exploration wells, so that oil and gas production also shrink, amidst low exploration efforts for new wells [20]. The following is the statistical data from SKK Migas regarding fluctuations in profit sharing of production from oil and gas sector:

\section{DIAGRAM 1}

FLUCTUATIONS IN PROFIT SHARING OF PRODUCTION FROM OIL AND GAS SECTOR

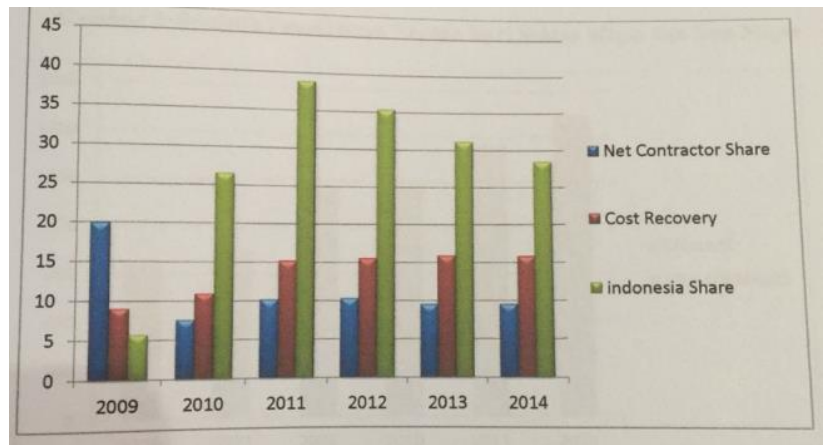

It can be seen that since 2009 the share of profit sharing between the Government and CCC shows a significant increase, until it reaches the highest curve in 2011, but then experiences profit sharing. Meanwhile, judging from the value of cost recovery in the upstream oil and gas industry since 2009-2013, there has always been an increase every year.

\section{DIAGRAM 2}

COST RECOVERY IN UPSTREAM OIL AND GAS INDUSTRY (IN MILLION US\$)

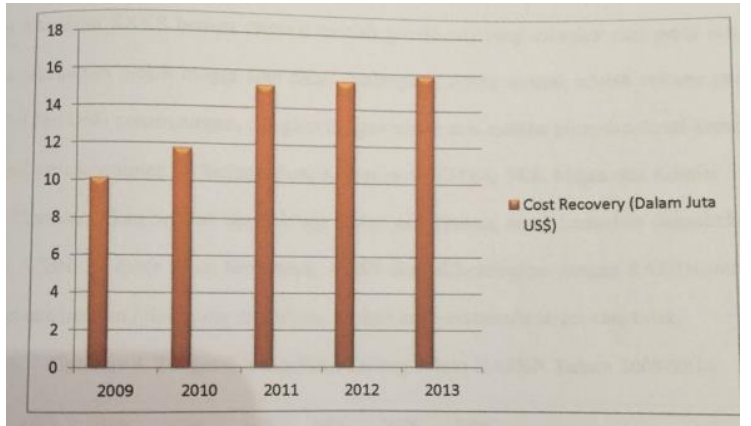

Source: SKK Migas Final Annual Report 2013

T ABLE 3

Cost Recovery VALUE GROWTH IN 2009-2013

\begin{tabular}{|c|c|c|c|c|c|}
\hline & $\mathbf{2 0 0 9}$ & $\mathbf{2 0 1 0}$ & $\mathbf{2 0 1 1}$ & $\mathbf{2 0 1 2}$ & $\mathbf{2 0 1 3}$ \\
\hline $\begin{array}{c}\text { Cost } \\
\begin{array}{l}\text { Recovery (in } \\
\text { Million US\$) }\end{array}\end{array}$ & 10,109 & 11,763 & 15,216 & 15,513 & 15,926 \\
\hline
\end{tabular}

One of the most important in PSC between the Government and the CCC is the existence of target in oil and gas production and lifting (oil lifting is the volume taken from the storage tank, transported by tankers or using pipes and sold to buyers or consumers)[21] to CCC in Indonesia. Every year, the Ministry of Energy and Mineral Resources, SKK Migas and Commission VII of the House of Representatives of the Republic of Indonesia set the target of daily and annual lifting quantities to be included in the National Budget. At the end of the following year, the State Budget will be compared with the Draft of State Budget to find out the produced lifting amount (whether reaching the target or not). As an example, in the 2014 State budget amendment, the initial oil lifting target was 870,000 barrels / day, which was later changed to 818,000 barrels / day, and for natural gas was 6,853 million cubic feet. As of 30 November 2014, the achievement of the lifting target of petroleum was 788,000 barrels / day, or only $97 \%$ from the target of the State Budget, while natural gas reached 98\% [22]. The efforts to fulfill the 2014 lifting target are constrained by the lack of new wells containing oil and gas, as well as the delay in Cepu Block project[23]. For the 2015 State Budget, the Ministry of Energy and Mineral Resources and Commission VII of the House of Representatives agreed to reduce the oil lifting target after deeper calculations, from 900,000 barrels / day to 825,000 barrels / day. The natural gas lifting rate is in the range of 1221 cubic feet / day. To meet the imposed lifting target imposed, the Government has prepared funds to the maximum cost recovery in 2015 as much as US \$ 16.5 billion, an increase from the previous year which was as much as US \$ 14 billion[24].

Lifting target is very influential to the state revenue because it is directly related to cost recovery. Oil and gas industry experiences one anomaly which is uncommon, namely when oil and gas productivity is low, the required production costs are actually higher, so that it may reduce state revenue from oil and gas sector[25]. When oil and gas production is below the lifting target, the Govern ment's share will be reduced, even though CCC has provided FTP $20 \%$ of Gross Revenue, whereas the amount of cost recovery that must be paid remains in accordance with the original payment target. Plus, when the situation of world oil prices falls, the burden of the Government will be heavier to lever State revenues from oil and gas sector.

\section{CONCLUSION}

Oil and gas sector contributes $28-30 \%$ of the total state revenue in the State budget. However, in 1996, oil and gas production began to show a decline, with its peak in 2005 where it declined from 1.4 million barrels / day to 930 thousand barrels / day. In addition to the natural decline, there are also technical issues, such as dried exploration wells, so that oil and gas production also shrink, a midst low exploration efforts for new wells. Uniquely, oil and gas industry has special characteristics compared to other industries, where the required production costs are actually higher, so that it may reduce state revenue from oil and gas sector. It is due to the cost recovery that must be paid, where the amount is still in accordance with the original payment target.

\section{REFERENCES}

Himpunan Peraturan Perundang-undangan di Bidang Pertambangan. 1991.

[2] S. HS, Hukum Pertambangan di Indonesia. Jakarta: Rajawali Press, 2014.

[3] C. Muhammad, indische Mijnwet dan Pertambangan di Era Kolonialisme. Bandung: Sinar Baru, 2002. 
[4] A. Nasir, Sejarah Sistem Fiskal Migas Indonesia. Jakarta: Grasindo, 2014.

[5] S. Nurdyanti, "Industri Migas," 2014. [Online]. Available: http:/t empoint erakt if.com/hg/perbankan keuangan/2010/04/06/br k,20100406-238268.id.html. . [Accessed: 04-Jul-2018].

[6] P. E. Wicaksono, "Penyimpangan Cost Recovery Migas akibat lemahnya Pengawasan." [Online]. Available: www.bloghukum.com/peny impangan-cost-recovery-migas-akibatlemahnya-pengawasan . [Accessed: 15-Jul-2018].

[7] I. Sutowo, Peranan Minyak dalam Ketahanan Negara. Jakarta: Sinar Grafika, 1970

[8] Bindemann, Production Sharing Agreement: An Economic analysis. UK: Oxford Institute for Energy Studies.

[9] M. Dharmasaputra and Dkk, Wajah Banu Industri Migas Indonesia. Jakarta: Kata Data, 2014.

[10] "Perlukah cost recovery dibatasi," Indomigas. [Online]. Available: http://www.indomigas.com/perlukah-cost-recovery-dibatasi/. [Accessed: 02-Aug-2018].

[11] I. A. Abdullah, "Bukan Pembatasan Cost Recovery, Tapi...,.," [Online]. Available: www.BisnisIndonesi.com. [Accessed: 02Aug-2018]

[12] "No Title." [Online]. Available: http://www.asray.com/_files/content/be74eb562e1d9c98aa937b10 91d7f5bce5d641c9.pdf.

[13] I. Sondi, "Bukan pembatasan cost recovery Melainkan...,.," [Online]. Available: www.kompasiana.com/read/bukanpembatasan-cost-recovery-melainkan.html. [Accessed: 02-Aug$2018]$.

[14] S. P. Utomo, Kedaulatan Migas dan Production Sharing Contract Indonesia. Jakarta: Reforminer Institute, 2010.

[15] M. Ashong, Cost Recovery in Production Sharing Contract: Opportunity for Striking it Richor Just Another Risk Not for Worth Bearing? US: University of Dundee, 2013.
[16]

"No

Title."

[Online]. Available: http://www.bppk.kemenkeu.go.id/id/berita-pajak/12592-prinsipkewajaran-dan-kelaziman.

[17] Buku Putih: Permasalahan kritis sector Migas dan dampaknya Bagi Perekonomian Indonesia . Jakarta, 2006.

[18] "Final Indonesia Annual Report SKK Migas 2013," SKK Migas. [Online]. Available: www.skkmigas.go.id/Final-IndonesiaAnnual-report-SKK-Migas-2013. [Accessed: 02-Aug-2018].

[19] R. D. Putrohari, Peran Industri Migas dalam Pembangunan di Indonesia. Jakarta: Universitas Trisakti, 2013.

[20] "Tentang SIstem Monitoring Ligting Migas," Department of Energy and Mineral Resource, Directorate General of Oil and Natural Gas. [Online]. Available: http://lift ing.migas.esdm.go.id/lift ing/informasi/tentang. [Accessed: 02-Aug-2018].

[21] "Lifting Migas dan Penerimaan Negara," Department of Energy and Mineral Resource, Directorate General of Oil and Natural Gas. [Online]. Available: www.esdm.go.id/artikel. [Accessed: 02Aug-2018].

[22] A. C.Utama, Kinerja Industri Hulu Migas 2014, December 2. Jakarta: SKK Migas, 2014.

[23] M. Adimaja, "SKK Migas Menyerah kejar target Lifting 2014." [Online].

Available: http://www.tempo.co/read/news/2014/03/01/090558457/SKKMigas-Menyerah-Kejar-T arget-Lift ing-Minyak-2014. [Accessed: 02-Aug-2018].

[24] A. Tjahya, "Komisi VII DPR RI dan Kementerian ESDM sepakat Usulan cost recovery." [Online]. Available: http://pedomannews.com/energi/30146-lagi-komisi-vii-dpr-danesdm-sepakat-usulan-cost-recovery-us165-m. [Accessed: 03-Aug2018 ].

[25] W. Partowidagdo, Migas dan Energi di Indonesia: Permasalahan dan Analisis Kebijakan. Jakarta: Development Studies Foundation, 2009. 